RJPSS March 2020 Vol. XLV No.1, ISSN: (P)0258-1701 (e)2454-3403 Impact Factor: 7.712

\title{
Transforming \& Empowering Rural Artisans and Grassroots Leaders Through Skill Development in India-Role of Handicrafts And Carpet Sector Skill Council (HCSSC)
}

\author{
Dr. Pushpa Chauhan*, Dr. S.P.Chauhan** \\ *Ex-Faculty of Music PGGCG sector 11 Chandigarh, \\ **Lecturer /Int Coordinator (CDTP) GPW Sector10-D,Chandigarh \\ Email:drsurenderchauhan940@gmail.com
}

\begin{abstract}
Transforming and empowering rural artisans and grassroots leaders through skill development in India is an imperative to make India a Developed Nation. In this process of development rural artisans and group leaders have a special role to play by becoming skilled person of society. The present Government rightly believes that for the sustainable growth rate of 10 per cent and development at the bottom of the pyramid, focus must be on skill development. The Prime minister often talks about Skill, Scale and Speed $\left(S^{3}\right)$. The issues of Scale speed, standard and sustainability has been addressed in new policy. Out of these three words, skill is most important. The Government of India, under the banner of Ministry of skill development and entrepreneurship has started many skill development schemes through NSDC and SSC. India has about 6.40 lacs villages spread over 329 Million Hectares of diverse geographical area having a wide natural and cultural bio-diversity. In the era when the whole world is facing major challenges of Climate Change due to carbon emission and pollution as a result of anthropogenic development process, we have to chalk out a judicious plan of sustainable rural development by empowering the rural artisans and group leaders. The objective of this paper is to study the role of Handicrafts and carpet sector skill council (HCSSC) in Transforming and empowering rural artisans and grass root leaders through skill development in India and the challenges they are facing. A notable aspect about these rural artisans is that they belong from the unorganized sector. These artisans on one hand are regarded as custodians of the heritage of India and on the other hand deprived of all the modern facilities and financial assistance.

Keywords: Transforming and empowering ,Rural artisans, Grassroots leaders, Unorganized Sector, Handicrafts and Carpet Sector Skill council (HCSSC) Skill, Scale and Speed (S3), NSDC-National Skill Development corporation, SSC-Sector skill councils.
\end{abstract}

Reference to this paper should be made as follows:

Received: 20.02.2020

Approved: 06.04.2020

Dr. Pushpa Chauhan, Dr. S.P.Chauhan,

Transforming \& Empowering Rural Artisans and Grassroots Leaders Through Skill Development in India

Article No. 10

RJPSS March 2020,

Vol. XLVNo. 1, pp. 075-086

Online available at: https://anubooks.com/ ?page id $=6389$

https://doi.org/10.31995/ ripss.2020.v45i01.010 
Transforming \& Empowering Rural Artisans and Grassroots Leaders Through Skill Development in India-Role of Handicrafts And Carpet Sector Skill Council (HCSSC)

Dr. Pushpa Chauhan, Dr. S.P.Chauhan

\section{Introduction-}

Transforming India to New India through various measures Digital India , Resurgent India, Transparent India, Incorruptible India, Clean India, Caring India, Emerging India, Investor-friendly India, Communicating India and last one is Skilling India. India having a third largest economy, has emerged as the fastest growing major economy in the world Skilling India is on top priority for next decade especially for youth artisans through various skill development schemes launched by GOI.

\section{Objectives of study}

$\varnothing$ To study the role of Handicrafts and carpet sector skill council (HCSSC) in Transforming and empowering rural artisans and grass root leaders through skill development in India

$\varnothing$ To examine the growth of Indian handicraft sector through SHG/agencies/ Panchayats in H.P and UK states.

$\varnothing$ To examine the existing and potential market and possible threats to the Indian handicrafts

$\varnothing$ To study the various destinations to export Indian handicrafts globally

$\varnothing$ To specify the problems faced by the handicraft sector and suggestions.

\section{Research Methodology}

The methods of research were combinations of secondary and primary method Secondary source -.The present study has been drawn heavily upon the relevant information from the secondary data where the data has been collected from the various reports, notifications, publications in Magazines and journals. The following web sites have also been studied: www.transformingindia.mygov.in http:// nsdcudaan.com/

\section{Primary source}

A primary investigation has been be carried out to complete the study, Data from some $\mathrm{NGO}$ /institutions working for artisans in H.P.

The following methods were used. Interview method and observation meth The SWOT analysis has also done to analyses the data.

Rural artisans and grass-root leaders

$\varnothing$ Rural artisans -person/families

$\varnothing$ Skilled workers who have practicing some trade/craft with hand with the 
RJPSS March 2020 Vol. XLV No.1, ISSN: (P)0258-1701 (e)2454-3403 Impact Factor: 7.712

help of tools and residing in rural area and earning their livelihood by doing handicraft work through their inherited skill mostly in unorganized sector.

$\varnothing$ Artisans are weavers, blacksmiths, carpenters, pottery ,cobbler, jewelers, embroidery and tailors

Ø Famous handicrafts-Pashmina shawls, woodwork especially bamboo products, pottery, jute and leather products, shell and brass products

$\varnothing$ Grass root leader GRLs- are volunteers appointed to serve in various grass root organization for artisans and rural development.

$\varnothing$ Indian Handicraft sector is second largest sector after agriculture in India

$\varnothing$ The Indian handicraft industry considered to be small scale and cottage industry helps to solve social and economic problems of the artisans,

$\varnothing$ providing employment to over 70 lakhs artisans (including those in the carpets trades) and more than 67,000 exporters / export houses promoting regional art and craftsmanship in the domestic and global markets

\section{The existing artisans are backbone of Indian handicraft industry}

Gifted with inherent skill, technique, traditional craftsmanship but that is quite sufficient for primary platform. However, in changing world market these craft persons need an institutional support, at their places i.e. craft pockets for value addition and for the edge with other competitors like China, Korea, Thailand etc Handicraft Industries in Rural India

The role of Handicraft Industries in Rural India Economy is very important Contribution towards the rural economy of India is increasing steadily. Handicrafts industry of India comes under the unorganized sector of village economy of India. The Handicrafts Sector plays a significant \& important role in the country's economy. It provides employment to a vast segment of Artisans in rural \& semi urban areas and generates substantial foreign exchange for the country, while preserving its cultural heritage

\section{India is basically an agriculture-based country}

Development of rural economy of India depends upon the development of its 700-million strong rural population. Majority of the population (around 70\%) lives in about 600,000 small villages.

The rural India is almost wholly agriculture based small part of the rural 
Transforming \& Empowering Rural Artisans and Grassroots Leaders Through Skill Development in India-Role of Handicrafts And Carpet Sector Skill Council (HCSSC)

Dr. Pushpa Chauhan, Dr. S.P.Chauhan

Indian population is engaged with small industries like handlooms, handicrafts and other traditional produce.

The role of Handicraft Industries in Rural India Economy became important, since today the organized sector of Indian industry is ready to absorb the products from these industries. Moreover, with liberal trade and export policy, the export of the Indian handicrafts industry is on an all time high.List of Area specific Indian Crafts

$\varnothing \quad$ Art metal ware

Moradabad, Sambhal, Aligarh, Jodhpur, Jaipur, Delhi, Rewari, Mhanjavur, Madras, Manpad, Beedar, Kerala and Jagadhari, Jalesher

$\varnothing \quad$ Wooden art wares

Saharanpur, Nagina, Hoshiarpur, Srinagar, Amritsar, Jaipur, Jodhpur, Jagdalpur, Bangalore, Mysore, Chennapatna, Madras / Manpad, Kerala and Behrampur (WB).

$\varnothing$ Hand-printed textiles

Amroha, Jodhpur, Jaipur, Farrukhabad, and Scarves Bagru and Sanganer.

$\varnothing \quad$ Embroidered goods

Kutch (Gujarat), Jaisalmer, Baroda, Lucknow, Jodhpur, Agra, Amritsar, Kullu, Dharamshala/Chamba and Srinagar.

$\varnothing$ Marble and soft stone

Agra, Madras, Baster, Jodhpur. Crafts Papier Mache crafts : Kashmir, Jaipur

$\varnothing \quad$ Terracota

Rajasthan, Madras, Baster.

$\varnothing \quad$ Zari and zari goods

Surat, Amritsar, Agra and Varanasi

$\varnothing \quad$ Imitation jewellery

Delhi, Moradabad, Sambhal, Jaipur, Kohima (Tribal)

$\varnothing \quad$ Artistic leather goods

Indore, Kolhapur, Shantiniketan (West Bengal).

Steps taken by the Government to boost and strengthen handicrafts sector

Providing Skill Development Training for Carpets weaving .Market Development Assistance (MDA) Grant and Market Access Initiative (MAI) 
Assistance for participation in Fairs \& Exhibitions/Reverse/Buyer-Seller Meets in India \& abroad. Assistance provided by the Government for marketing study, branding/ International publicity, participation in Fairs \& Exhibitions, Buyer-Seller Meet in India $\&$ abroad etc. through Marketing and other Schemes. Thematic display and live demonstration of crafts by Master Crafts persons in exhibitions abroad

Skill Development Schemes of Govt. of India (GOI) Skill Development Scheme The Skill Development Initiative scheme was started by M/o Labour, GOI for the Workers seeking certification of their skills acquired informally. Workers and ITI graduates seeking skill up-gradation, early school drop-outs and unemployed free of cost. Skill Development Initiative on Modular Employable Skill (MES) has been developed in close consultancy with Industry, State Governments \& Experts in pursuance of excellence in vocational training.

\section{National Skill Development Corporation (NSDC)}

National Skill Development Corporation (NSDC) as a Public Private Partnership entity to promote private training providers across the country. NSDC has incubated 37 SSCs which are industry led bodies intended to align the skilling efforts as per the industry's requirement. The SSCs prescribe the National Occupational Standards (NOS) and QPs based on which the training is imparted.

Pradhan Mantri Kaushal Vikas Yojana (PMKVY) Pradhan Mantri Kaushal Vikas Yojana (PMKVY) is the flagship outcome-based skill training scheme of the new Ministry of Skill Development \& Entrepreneurship (MSDE).

The objective of this skill certification and reward scheme is to enable and mobilize a large number of Indian youth to take up outcome based skill training and become employable and earn their livelihood.

\section{Role of Handicrafts And Carpet Sector Skill Council ( HSSSC)}

$\varnothing$ Creating skill development plan for the Handicrafts and Carpet sector

$\varnothing$ Developing skill competency based on qualifications and standards

$\varnothing$ Capacity building of young artisans to strengthen their skills and skill up gradation of existing artisans

$\varnothing$ Developing Labour Market Information System (LMIS) for the Handicrafts and Carpet sector

$\varnothing$ Improving training delivery and promotion of academies of excellence 
Transforming \& Empowering Rural Artisans and Grassroots Leaders Through Skill Development in India-Role of Handicrafts And Carpet Sector Skill Council (HCSSC)

Dr. Pushpa Chauhan, Dr. S.P.Chauhan

\section{Performance of HSSSC till date 2018-19}

\section{HSSSC -}

$\varnothing$ Training partners -45 no,s

$\varnothing$ Trainee enrolled-1,41,475,

$\varnothing$ Trainee trained-1,34,362

$\varnothing \quad$ Trainee assessed- $1,31,870$

$\varnothing$ Trainee certified-1,30,052

$\varnothing$ Assessment partners-04

\section{Role of HCSSC in empowering and transforming rural artisans and grassroots} leaders in India

The Handicrafts and Carpet Sector Skill Council (HCSSC) has been formed to promote skill development among artisans, craft persons and workers at grass root levels.

This would enable them to adopt latest techniques and become more productive. Sector Skill Councils (SSCs) are Industry-led bodies which are responsible for the defining the skilling needs, concept, processes, certifications and accreditation of their respective industry sectors in accordance with National Skill Qualification Framework (NSQF).

The HCSSC shall be responsible for meeting the human resource requirement in terms of shop floor workers and professionals for the entire value chain of the handicraft and carpet industry.

There are 37 SSCs in India in almost all major areas including agriculture, life science etc.

The SSCs which have designed as many as 1,034 Qualification Packs (QPs) and 3,464 National Occupational Standards (NOS) are operating throughout India. Training is one of the fundamental elements of the skill development process. The training conducted by HCSSC can be segregated into three different segments.

$\varnothing$ Training of Trainees

$\varnothing$ Training of Trainers (TOT)

$\varnothing \quad$ Training of Assessors (TOA)

\section{Assessment}


RJPSS March 2020 Vol. XLV No.1, ISSN: (P)0258-1701 (e)2454-3403 Impact Factor: 7.712

Proper assessment of the trainees is one of the most important parts of the skill development process.

The quality of assessment would define the standard of the trained trainees. For that matter, HCSSC has affiliated assessment agencies to conduct the assessments as per the standards set by NSDC and HCSSC.

The assessment agencies have assessors who assess the trainees on the set standards.

In order to guide and assist the assessors, HCSSC conducts Training of Assessors (TOA) (for more information check the Training of Assessors section of the Training tab).

\section{Certification}

$\varnothing$ Certification is the final process of the skill development process.

$\varnothing \quad$ After the completion of training delivered by certified trainers at affiliated training centers, the trainees are assessed by certified assessors.

$\varnothing$ These assessors evaluate the trainees on the basis of the various standards set by NSDC and HCSSC.

$\varnothing$ On successfully completing the training and assessment, depending on the grades/marks obtained in the assessments, the trainees are certified.

$\varnothing$ The certification process includes the grading of trainees with respect to the marks/grades earned in the evaluation procedure. Subsequently, the trainees are offered their certificates.

\section{Case studies of some artisans/group leaders from HP and UK}

\section{Community based Tourism - HP}

$\varnothing$ Community base activities in villages including skill development training are being executed in partnership with NGO/SHG-agencies and group leaders

$\varnothing$ Working for development rural artisans since 2011 under tourism department and skill development board.

$\varnothing$ Ms Sudarshana from-Mahila Kangra sabha was the skill development trainer for rural artisans especially embroidery and knitting work,Home made products

\section{Group leaders}

Mr Ishue Thakur who is MBA Rural development from this NITTTR Chandigarh through HPU Shimla working for the development of artisans. 
Transforming \& Empowering Rural Artisans and Grassroots Leaders Through Skill Development in India-Role of Handicrafts And Carpet Sector Skill Council (HCSSC)

Dr. Pushpa Chauhan, Dr. S.P.Chauhan

Govt. of Himachal is helping in publicity through exhibitions and craft mela at local

level and state level

\section{Maximum publicity is through social media}

Providing loans through regional rural banks and co-operative banks in HP.Other group leaders working for artisans in HP

$\varnothing$ Ms Anita Thakur from Mahi Panchayat Distt Solan

$\varnothing \quad$ Ms Sunita Devi ,Ms Indira Thakur ,Ms Bhima Bharti and Ms Nirmla and Mr Tula Ram-Distt Mandi

$\varnothing$ Ms Nirmal Ji from Baldeya Panchayat runing her Home stay business and Mr Vikash Sharma is helping her from HP. She has earned 1.5 lac in 07 months in last season being a artisan

$\varnothing$ All the products are being sold through Hotel and on -line marketing.

\section{Centre For Indian Bamboos Resource And Technologies (CIBART )}

The artisans are getting Skill development Training through this resource centre in HP. The training is provided free of cost and stipend amounting to Rs 150 per day is given to artisans of 20 no.s batch size

$\varnothing$ The 150 artisan have been trained through skill development scheme through CIBART till date

$\varnothing$ And all are earning average monthly wages Rs 3000-5000 part timely.

\section{Group leaders}

Mr Vinod from Utrakhand working in this project with salary 15000/per month as trainer as well as grass-root group leader and providing skill development training to artisans.

Mr Sanjay from Himachal working in this project with salary 15000/per month as trainer as well as grass-root group leader

Mr Vinod artisans group leader and trainer

Newspaper clips of Mr Vinod from UK

Mr Sanjay from HP working in this project with salary 15000/per month as trainer as well as grass-root group leader

\section{Destination in foreign Markets-}

Major buyers for handicrafts (other than carpets)

$\varnothing$ Art metal wares—uSA, Germany, UK, Netherlands and UAE 
RJPSS March 2020 Vol. XLV No.1, ISSN: (P)0258-1701 (e)2454-3403 Impact Factor: 7.712

$\varnothing$ Wood wares__ USA, UK, UAE, Germany and France

$\varnothing$ Hand printed and textiles and scarves-USA, UK, Germany, UAE and Canada

$\varnothing$ Embroidered and crocheted goods-USA, UK, Germany, UAE and France

$\varnothing$ Shawls as artwares-UAE, USA, UK, France and Germany

$\varnothing$ Zari and zari goods-USA, UK, Italy, Germany and France

$\varnothing$ Imitation jewellery_USA, UK, Japan, Italy and Germany

$\varnothing$ Miscellaneous handicrafts-USA, Germany, UK, Japan and UAE

\section{Indian Handicrafts Swot Analysis}

\section{Strengths:}

$\varnothing$ Availability of unique local raw materials e.g. natural fibers, bamboo, cane, horn, jute, leather, etc.

$\varnothing$ Rich and diversified culture producing wide range of unique and exclusive handicrafts.

$\varnothing \quad$ Strong existing pool of skilled artisans.

$\varnothing$ Wide range of traditional production skills derived from indigenous knowledge.

$\varnothing$ High potential for empowerment of women, youth and people with disabilities.

$\varnothing$ Low production costs

\section{Opportunities:}

$\varnothing$ Increasing emphasis on product development and design up gradation.

$\varnothing$ Rising demand in domestic and traditional market.

$\varnothing$ Rising appreciation by consumers in the developed countries.

$\varnothing$ Government support and interest in preserving the craft.

$\varnothing$ Emerging markets in Latin America, North America and European countries.

$\varnothing \quad$ Fair trade practices.

$\varnothing$ Increasing flow of tourists provide market for products

\section{Weaknesses:}

$\varnothing$ Lack of design, innovation and technology up gradation.

$\varnothing$ Highly fragmented industry.

$\varnothing$ Unstructured and individualized production systems.

$\varnothing$ Lack of strong umbrella sector organizations.

$\varnothing$ Limited capitalization and low investment. 
Transforming \& Empowering Rural Artisans and Grassroots Leaders Through Skill Development in India-Role of Handicrafts And Carpet Sector Skill Council (HCSSC)

Dr. Pushpa Chauhan, Dr. S.P.Chauhan

$\varnothing$ Insufficient market information on export trends, opportunities and prices.

$\varnothing$ Limited access to credit.

$\varnothing$ Limited resources for production, distribution and marketing.

$\varnothing$ Limited e-commerce competence among producer groups.

$\varnothing$ Lack of adequate infrastructure, absence of latest technology

$\varnothing$ Handicrafts sector is not mainstreamed in planning priorities of many State Governments.

\section{Threat}

$\varnothing$ Decreasing supply of good quality raw material.

$\varnothing$ Increasing threat from Asian countries.

$\varnothing$ Better quality components, findings and packaging in other countries.

$\varnothing \quad$ Lack of quality standardization process.

$\varnothing$ Declining investment in the sector (largely in the developed economies) and increasing consumer sophistication.

$\varnothing$ Absence of institutional support.

$\varnothing$ High freight costs associated with air cargo and shipment.

$\varnothing$ High cost of production rendering Indian crafts less competitive in the markets.

\section{Finding of study}

$\varnothing$ Lack of interest by second generation - Rural youth are increasingly disinterested in continuing their family craft traditions due to having seen their parents struggle to find markets and fair prices for their products, they are inclined to pursue other trades.

$\varnothing$ The Education system has integrated lessons regarding the importance of crafts into the Technical institutions, school curriculum, but not properly implemented so students are pushed towards white collar office jobs, even if they are lower paying.

$\varnothing$ Finally, crafts are strongly associated with a family's caste. In many cases, such as leatherwork, artisans are ostracized for being from the lowest caste, which further dissuades rural youth from joining the family

$\varnothing$ The Handicraft sector has, however, suffered due to its being unorganized, with the additional constraints of lack of education, low capital, and poor 
exposure to new technologies, absence of market intelligence, and a poor institutional framework. In spite of these constraints, sector has witnessed a significant growth of $3 \%$ annually.

$\varnothing$ It faces imminent threat from the growing clout of Chinese economy coupled with their cheap yet disciplined labour as also from superior quality products manufactured by developed countries. However Indian handicraft has great growth potential in the changing scenario with its basic strength being the abundant and cheap availability of manpower and being a traditional profession of millions still requires very low investment compared with other countries barring china.

\section{Suggestions/recommendations}

$\varnothing$ Free entry Indian Handicrafts \& Gifts Fairs in all over India.

$\varnothing \quad$ Free of cost training to rural artisan with stipend should be given at door step through community development skill development scheme.

$\varnothing$ To provide technological support to all artisans in India through transfer of rural technologies.

$\varnothing \quad$ Setting up of Mega cluster centre in each state to increase manufacturing and exports of handicrafts and carpets.

$\varnothing \quad$ The entire handicraft should be tax free.

$\varnothing$ Interest free Financial help through SHG and RRBs

$\varnothing$ Interest subvention and grant of MUDRA loan schemes to the handicrafts artisans so as to compete with machine-made products.

$\varnothing$ Awards for best artisan in India should be declared for motivation.

\section{Conclusion:}

The Handicrafts Sector plays a significant \& important role in the country's economy. It provides employment to a vast segment of artisans in rural \& semi urban areas and generates substantial foreign exchange for the country, while preserving its cultural heritage. Handicrafts have great potential, as they hold the key for sustaining not only the existing set of millions of artisans spread over length and breadth of the country, but also for the increasingly large number of new entrants in the crafts activity. Presently, handicrafts contribute substantially to employment generation and exports. Craft is the standard mark of creativity and the essential 
Transforming \& Empowering Rural Artisans and Grassroots Leaders Through Skill Development in India-Role of Handicrafts And Carpet Sector Skill Council (HCSSC)

Dr. Pushpa Chauhan, Dr. S.P.Chauhan

differentiator for a country in the sweeping wines of globalization. Most importantly, craft has to become a fountainhead for both industrial design and communication design, for deriving the differential advantage of Indian design in the global market place. The highest demand handicrafts in India and abroad are handmade sarees, imitation jewelry and home decorative items.

\section{References}

1 www.transformingindia.mygov.in

2 http://nsdcudaan.com/

3 https://www.msde.gov.in/

4 http://www.hcssc.in/

5 https://www.nsdcindia.org/sector-skill-councils-1 